Original Article

\title{
Anthelmintic usage on the performance of the Agouti (Dasyprocta leporina) reared intensively in Trinidad and Tobago, West Indies
}

\author{
Uso de anti-helmíntico no desempenho da cutia (Dasyprocta leporina) criada \\ intensivamente em Trinidad e Tobago, Índias Ocidentais
}

\section{K. R. Jones ${ }^{\mathrm{a}, \mathrm{b} *}$ (D) and G. W. Garcia ${ }^{\mathrm{b}}$ (D)}

aUniversity of the West Indies - UWI, School of Veterinary Medicine - SVM, The Department of Basic Veterinary Sciences - DBVS, Mt. Hope, Trinidad and Tobago

${ }^{\mathrm{b}}$ The University of the West Indies - UWI, Faculty of Food and Agriculture - FFA, Department of Food Production - DFP, The Open Tropical Forage-Animal Production Laboratory - OTF-APL, St. Augustine, Trinidad and Tobago

\begin{abstract}
Anthelmintic drugs have been used strategically in livestock reared in the tropics. These drugs have been used in the treatment of endoparasitism which have resulted in an increase in the animals' performance. The agouti (Dasyprocta leporina) is a neo-tropical rodent with the potential for domestication and has been farmed intensively in Trinidad. However, the objective of this research was to investigate the effect of anthelmintic use of the growth performance of the agouti. In searching the literature, it was found that this type of study on the agouti has not been done. In this experiment fourteen weaned agoutis weighing $1 \mathrm{~kg}$ were divided into two groups randomly. The first group $\left(T_{1}\right)$ was not given any anthelmintic treatment but the second group $\left(T_{2}\right)$ was treated with Endovet Ces ${ }^{\circledR}$ subcutaneously every three months. There were no significant differences $(\mathrm{p}>0.05)$ between the two groups in the carcass weight, weight gain, dressing percentage (hot and cold), heart, lungs, skin, head and feet. However, a significant difference ( $p<0.05$ ) was seen between groups in the weight of liver and pluck. To the authors knowledge this is the first time that carcass parameters has been presented in literature. The live weight of the animals at the end of the experiment ranged from $2.4 \mathrm{~kg}$ to $2.6 \mathrm{~kg}$ and animals had a dressing percentage of $57 \%$ to $55 \%$. The results are suggestive that the use of anthelmintic drugs in agoutis reared intensively had no significant effect on weight gain and dressing percentage.
\end{abstract}

Keywords: Dasyprocta leporina, agouti, anthelmintic, dressing percentage, Trinidad.

\begin{abstract}
Resumo
Drogas anti-helmínticas têm sido usadas estrategicamente em rebanhos criados nos trópicos. Essas drogas têm sido utilizadas no tratamento do endoparasitismo, o que resultou em um aumento no desempenho dos animais. A cutia (Dasyprocta leporina) é um roedor neotropical com potencial para domesticação e tem sido criada intensivamente em Trinidad. Porém, o objetivo desta pesquisa foi investigar o efeito do uso de anti-helmínticos no desempenho de crescimento da cutia. Através de uma busca na literatura, constatou-se que esse tipo de estudo na cutia não foi realizado. Neste experimento, quatorze cutias desmamadas pesando $1 \mathrm{~kg}$ foram divididas em dois grupos aleatoriamente. $O$ primeiro grupo (T1) não recebeu nenhum tratamento anti-helmíntico, mas o segundo grupo (T2) foi tratado com Endovet Ces ${ }^{\circledR}$ por via subcutânea a cada três meses. Não houve diferenças significativas $(p>0,05)$ entre os dois grupos no peso da carcaça, ganho de peso, porcentagem de cobertura (quente e frio), coração, pulmão, pele, cabeça e pés. No entanto, uma diferença significativa $(\mathrm{p}<0,05)$ foi observada entre os grupos no peso do fígado e depenagem. Para os autores, esta é a primeira vez que parâmetros de carcaça são apresentados na literatura. $\mathrm{O}$ peso vivo dos animais ao final do experimento variou de $2,4 \mathrm{~kg}$ a $2,6 \mathrm{~kg}$ e os animais tinham uma porcentagem de curativo de $57 \%$ a $55 \%$. Os resultados sugerem que o uso de anti-helmínticos em cutias criadas intensivamente não teve efeito significativo no ganho de peso e na porcentagem de curativo.
\end{abstract}

Palavras-chave: Dasyprocta leporina, cutia, anti-helmíntico, porcentagem de curativo, Trinidad.

*e-mail: keganjones11@gmail.com

Received: December 18, 2020 - Accepted: February 08, 2021 


\section{Introduction}

Neotropical animals with the potential for domestication are an important food source for rural communities They provide a level of food security and hunger reduction in rural areas (Brown-Uddenberg et al., 2004; Nunes et al., 2019). Brown-Uddenberg et al. (2004) named the agouti (D. leporina) as one of several neo-tropical animals with the potential for domestication. The farming of the agouti is one method of ex situ conservation. These animals were termed micro-livestock or mini-livestock (NRC 1991, Hardouin et al., 2003) and can be reared intensively to provide commodities (meat, skin, hides) which can be utilized by humanity.

Animals present in the Neo-tropics can be divided into three categories. Animals present in the first category consists of domesticated animals (cattle, sheep, goat, chickens, horses) that were introduced in the Neo-tropics (Jones and Garcia, 2018a). The second category consists of domesticated Neo-tropical animals (alpacas, vicunas, ducks, llamas, chinchillas, guinea pigs) (Jones and Garcia, 2019). The third category is non-domestic neo-tropical animals (Jones et al., 2019c). The agouti (D. leporina) resides within the category of non-domesticated neotropical animals.

The agouti is a hindgut fermenter with a large caecum (Garcia et al., 2000). In captivity the preferred feed particle size is $12.7 \mathrm{~mm}$ x $25.4 \mathrm{~mm}$ (Dookie et al., 2018), and exhibited scatter hoarding behaviour (Emmons and Feer, 1997; Ramdial and Ramdial, 1974). Many authors have considered this animal as a frugivore (Henry, 1999; Silvius and Fragoso, 2003, Dubost and Henry, 2006, Lall et al. 2018a). However, in recent times the agouti was found to exhibit omnivorous behaviour (Figueira et al., 2014, Jones et al., 2019b) and in some cases cannibalistic behaviour (Smith and Smith, 2019). These animals can be fed local feedstuff which make them ideally suited for the intensive production (Brown-Uddenberg et al., 2004).

However, if these animals are to be reared intensively to be utilized by humans then stress levels in these animals will be increased. Increased levels of stress predispose these animals to diseases. Therefore, the knowledge of diseases which can affect these animals must be known. Lall et al. (2018b) highlighted several pathogenic organisms that can invade these animals. Pathogenic diseases are very costly to livestock production and one of the major pathogens which affect livestock is parasites.

In Neo-tropical animals Jones et al. (2019c) summarized parasitic organisms that affect these animals. It was found that few animals exhibited clinical diseases and few authors reported the effect of the parasites on animals. The agouti has been found with gastrointestinal parasites in captivity as well as in the wild. In Trinidad Suepaul et al. (2016) identified a cestode, a trematode, an ascarid like worm, Strongyloides spp., Helminthoxy urichi and Trichuris spp. Jones and Garcia (2017, 2018b) found similar parasites to Suepaul et al. (2016) but animals were in good body condition.

Reports in other countries on the endoparasites in the agouti have been reported, in Brazil (Goncalves et al., 2007; Lainson et al., 2007, da Silva et al., 2008; Ramos et al., 2016), Paraguay (Cassone and Durette-Desset, 1991) and Guyana
(Zimmerman et al., 2009). However, most authors failed to record the effects the parasites had on the animals. The objective of this paper was to investigate the effect of anthelmintic on the weight gain and carcass parameters in the agouti reared intensively.

\section{Methodology}

\subsection{Location and climate}

The agouti ( $D$. leporina) was housed at the Neo-tropical animal unit located at the University of the West Indies (UWI) Field Station, Valsayn, Trinidad. The building is open sided which allowed animals to be well ventilated. Trinidad and Tobago is located in the humid tropics and experiences an average day temperature of $32^{\circ} \mathrm{C}$, with an average of $22^{\circ} \mathrm{C}$ recorded at night. The average humidity recorded was $82 \%$ with an average rainfall of $1000 \mathrm{~mm}$.

\subsection{Housing of the Agouti at the University Field Station}

The building of the agouti unit is open sided which allows animals to be well ventilated. Agoutis in this experiment were reared in individual cages. The unit has a current capacity of one hundred and twenty animals. However, fourteen animals were taken at weaning for this project. The sample size of fourteen animals was due to the limited availability of this physiological state of this non- domesticated species (wild species) In this experiment animals were taken after weaning and placed in individual cages for the duration of the experiment (14 months). All applicable international, national, and/or institutional guidelines for the care and use of animals were followed. The research site has been overseen by veterinarians to ensure animals are kept healthy. Field and laboratory protocols were approved by the Ethics Committee of the University of the West Indies, Faculty of Food and Agriculture, University of the West Indies, St. Augustine campus (ref no. CEC 246/05/17).

\subsection{Experimental design}

Fourteen weaned agoutis were taken weighing approximately $1000 \mathrm{~g}$. These animals were randomly divided into two groups. The first group of animals $\left(T_{1}\right)$ were not given any anthelmintic treatment for the duration of the experiment. The second group $\left(\mathrm{T}_{2}\right)$ was given Endovet Ces ${ }^{\circledR}$ (Ivermectin/ praziquantel) subcutaneously at $0.5 \mathrm{mg} / \mathrm{kg}$ every three months. The experiment spanned for 14 months, beginning in May 2018 and concluding in July 2019.

At the end of the experiment animals of both groups were slaughtered humanely by veterinarians. The live-weight as well as the body condition of the animals were taken pre-slaughter. The blood was also collected from the animals via the jugular vein as well as gastrointestinal contents from the rectum collected. The hot carcass weights as well as the weights of visceral organs, skin, head, and feet were taken. The carcasses were then chilled for 24 hours and a cold carcass weight was taken. Body condition score 
was given to each animal before slaughter and pictures of representative animals were taken.

\subsection{Blood and Gastrointestinal content analysis}

Blood was collected from the jugular vein and placed into purple (EDTA) and red top tubes for haematological and biochemical analyses. The blood samples that were taken were refrigerated $\left(4^{\circ} \mathrm{C}\right)$ overnight and analysed at Animedics Pet Hospital located in Chaguanas. The blood was analysed using the Abaxis systems (VETSCAN ${ }^{\circledR}$ VS2 Chemistry Analyser and VETSCAN® HM5 Hematology Analyser

Gastrointestinal samples were collected and analysed using faecal floatation techniques (Hendrix and Robinson 2016). Three grams of gastrointestinal content were taken and mixed with $45 \mathrm{mls}$ of a $33 \%$ Zinc Sulphate solution. The mixture was then strained to remove excessive debris. The filtrate was then taken and filled into a measuring cylinder until a positive meniscus was obtained. The mixture was then allowed to settle for fifteen minutes. A cover slip was then placed on the top to the measuring cylinder and placed onto a microscopic slide. This slide was then viewed under a light microscope for identification of endoparasitic eggs or ova. The faecal analysis was done at the Parasitology Laboratory at the School of Veterinary Medicine which is located in Mt. Hope.

\subsection{Diet of the Agouti (D. leporina) at the University Field Station}

The animals were fed a variety of local fruits and forages which could be found on the premises of the farm. These included; breadfruit (Artocarpus altilis), guavas (Psidium guajava), pumpkins (Cucurbita pepo) and mangoes (Mangifera indica). The agoutis were also supplemented with approximately $200 \mathrm{~g}$ of Rabbit Rations formulated by National Flour Mills ${ }^{\circledR}$ and chicken (Gallus domesticus) eggs daily. Throughout the experiment the agouti was given water ad libitum.

\subsection{Statistical analysis}

Data obtained from the study were summarized as means \pm standard deviation. Student t-test analysis using SPSS (20) and a significance level of $\mathrm{p}<0.05$ was used throughout the experiment.

\section{Results}

The blood parameters of the sacrificed animals fell within the normal limits for agouti housed in captivity (Jones et al., 2019a, Baas et al., 1976). No gastrointestinal eggs or oocysts were found in the faecal samples that were taken from the rectum. Adult worms were also not found in the rectal samples collected from the agouti. The animals had a body condition score of 4 out of 5 (Ullman-Cullere and Foltz, 1999). The animals had a good covering of flesh before slaughter (See Figures 1-2).

There was no significant difference $(p>0.05)$ in the growth, hot carcass, cold carcass, hot dressing percentage, cold dressing percentage, gastrointestinal tract(GIT), lungs, kidneys, heart, feet and skin between the two treatment groups. The weight of the liver and pluck had significant differences $(\mathrm{p}<0.05$ ) between the two groups (Table 1 ).

The animals which were dewormed had significantly higher $(p=0.042)$ pluck weight than the animals that were not dewormed. Agoutis that were dewormed also had significantly $(\mathrm{p}=0.02)$ heavier livers than animals not exposed to the deworming agent (Table 1 ). The experimental animals had live weight ranging between $2.4 \mathrm{~kg}$ and $2.6 \mathrm{~kg}$. The animals in both treatments gain an average between $1.6 \mathrm{~kg}$ and $1.7 \mathrm{~kg}$ during the entire experiment (14 months). On average the hot dressing percentage of the agouti in this experiment was $57.1 \%$ and cold dressing percentage was between $55.9 \%$ - 57.6\%.

The average weight of the heart was between $32.7 \mathrm{~g}$ and $34.7 \mathrm{~g}$, the kidneys averaged $30.4 \mathrm{~g}$ and $32.1 \mathrm{~g}$ and the lungs weighed between $37.6 \mathrm{~g}$ and $45.0 \mathrm{~g}$ (Table 1 ). The head weighed between $237.1 \mathrm{~g}$ and $241.0 \mathrm{~g}$, the weight of the skin ranged from 341.3 and $381.3 \mathrm{~g}$ whilst the weight of feet of the agouti ranged from $85.2 \mathrm{~g}$ to $93.0 \mathrm{~g}$ (Table 1 ).

\section{Discussion}

The live weight obtained in this experiment for both treatments were $2.4 \mathrm{~kg}$ and $2.6 \mathrm{~kg}$. Live weight of adult agoutis recorded in literature was between $2 \mathrm{~kg}$ to $4 \mathrm{~kg}$ (Baas et al., 1976; Eisenberg and Redford, 1999; Brown-Uddenberg et al., 2004; Mc Williams, 2009). Data

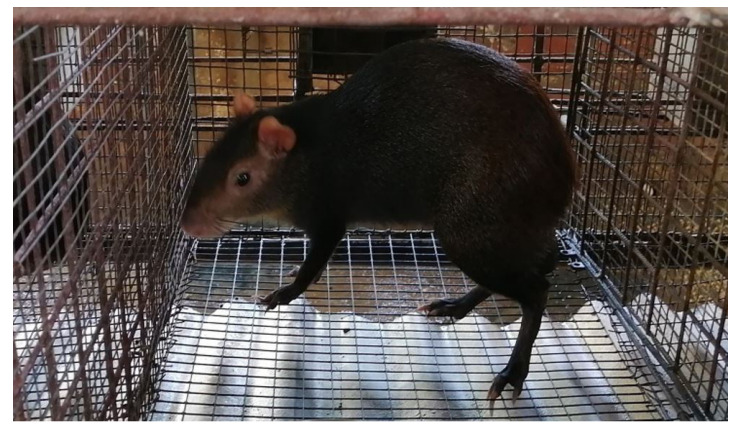

Figure 1. Agoutis reared in experimental cages before slaughter in excellent condition with shiny coats.

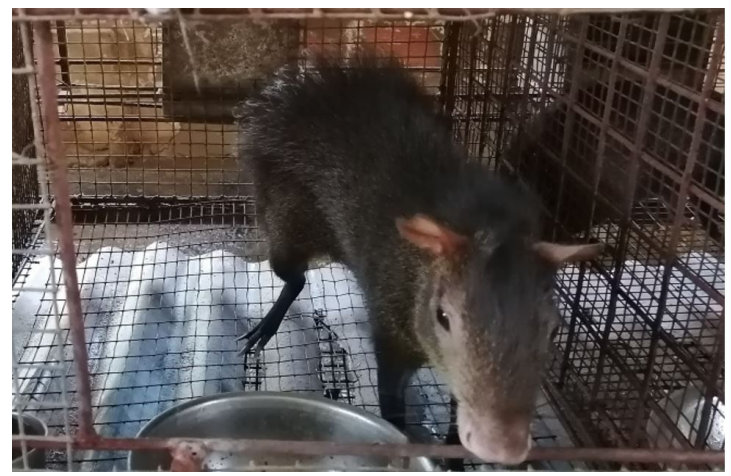

Figure 2. Male agouti reared individually in experimental cages. 
Table 1. Carcass parameters of the Agouti (D. leporina) reared with and without exposure to anthelmintic treatments.

\begin{tabular}{|c|c|c|c|c|}
\hline Parameters & $T_{1}$ (no anthelmintic) & $\mathrm{T}_{2}$ (anthelmintic) & SEM & P-Value \\
\hline Live weight ( $g$ ) & $2413 \pm 228$ & $2643 \pm 164$ & - & - \\
\hline Growth (g) & $1605 \pm 256$ & $1713 \pm 333$ & 157 & 0.511 \\
\hline Hot Carcass (g) & $1380 \pm 130$ & $1580 \pm 102$ & 131 & 0.058 \\
\hline Hot Dressing percentage (\%) & $57.19 \pm 1.71$ & $57.14 \pm 1.65$ & 0.91 & 0.963 \\
\hline Cold Carcass (g) & $1389 \pm 140$ & $1476 \pm 108$ & 67.62 & 0.214 \\
\hline Cold Dressing percentage (\%) & $57.57 \pm 2.55$ & $55.89 \pm 2.94$ & 1.49 & 0.274 \\
\hline Pluck (g) & $358.4 \pm 61.1^{\mathrm{a}}$ & $427.9 \pm 53.0^{\mathrm{b}}$ & 30.89 & 0.042 \\
\hline Gastrointestinal tract (g) & $216.1 \pm 40.1$ & $261.1 \pm 48.8$ & 24.1 & 0.084 \\
\hline Lungs (g) & $37.57 \pm 4.86$ & $45.00 \pm 9.97$ & 4.23 & 0.102 \\
\hline Liver (g) & $88.86 \pm 9.56^{\mathrm{a}}$ & $104.00 \pm 3.56^{\mathrm{b}}$ & 3.90 & 0.002 \\
\hline Kidney (g) & $30.43 \pm 3.46$ & $32.14 \pm 2.41$ & 1.61 & 0.303 \\
\hline Heart (g) & $32.71 \pm 5.02$ & $34.67 \pm 4.50$ & 2.58 & 0.480 \\
\hline Head (g) & $241.0 \pm 27.7$ & $237.1 \pm 27.1$ & 14.8 & 0.797 \\
\hline Feet $(g)$ & $93.00 \pm 7.48$ & $85.29 \pm 18.36$ & 7.57 & 0.324 \\
\hline Skin (g) & $341.3 \pm 44.0$ & $381.4 \pm 32.2$ & 20.8 & 0.75 \\
\hline
\end{tabular}

a, b Superscripts denotes statistical significance $(\mathrm{p}<0.05)$ between rows

on the carcass of the agouti was never recorded in the literature. However, the dressing percentage found (57\% to $55 \%$ ) were similar to neo-tropical animals such as the collared peccary (P. tajacu/ T. tajacu) and the capybara (H. hystrochaeris). The dressing percentage of the capybara ranged from 51\% to 55\% (Saadoun and Cabrera, 2008; Pinheiro and Moreira et al., 2012) and that for the collared peccary was between $52.1 \%$ to $60.4 \%$ (Saadoun and Cabrera, 2008; Albuquerque et al., 2010, 2012).

There were significant differences in the weight of the pluck and the liver amongst the two treatment groups. The pluck of the agouti comprised of organs that were present in the thoracic and abdominal cavity. The difference in the weight of the pluck between the treatments was due to the liver weight. These differences between treatments were not expected. It should be noted that this type of experiment was never performed on the agouti and baseline information was obtained. The liver was the only organ in the animal with significant difference between the two groups. This document contains the first record of the use of anthelmintic in the rearing of the agouti. The anthelmintic used was endovet Ces ${ }^{\circledR}$ which reduces the number of endoparasites in domesticated livestock. It contains ivermectin and praziquantel which can be used to treat roundworms and flatworms (Hendrix and Robinson, 2016).

The experiment results suggested that the use of endovet $\mathrm{Ces}^{\circledR}$ had no effect on the live weight and most of the carcass traits that were recorded. Interestingly, a similar experiment was done on weaned alpacas (Vicugna pacos) and dewormed animals had a significant reduction in live weight as compared to the negative control (animals given no dewormer) (Thomas and Morgan, 2013). The experiment on alpacas and agoutis in this experiment suggests that endoparasites may not be detrimental to the animals. Endoparasites have been found in the agouti in the Neo-tropics. Some of the endoparasites identified were Stichorchis giganteus, Raillietina demerariensis var. trinitatae, Strongyloides agouti, Trichuris gracilis var. trinitatae, Acanthocheilonema spp., Fuellebornema agoutii, Pudica pudica, Apidodera binansata var. agoutiae, Helminthoxys urichi, Eimeria aguti, E. cotiae and E. paraensis (Griffiths, 1940; Cameron and Reesal, 1951; Goncalves et al., 2007; Lainson et al., 2007; da Silva et al., 2008; Suepaul et al., 2016, Jones and Garcia, 2017, 2018b) but in this experiment endoparasitic eggs were not identified using faecal floatation techniques. The absence of endoparasitic eggs does not imply that endoparasites were absent in these animals. Faecal floatation can be inconclusive in cases were the parasites have not reach maturity. Female helminths may also shed eggs periodically if the animal is stressed, thus if faeces is collected in non-stressful situation eggs will not be present in the faeces (Soulsby, 1968).

Earlier work done by Jones and Garcia (2017, 2018b) stated that the gastrointestinal parasites had no effect on the animals' body condition. Trichuris gracilis, Paraspidoera uncinata, Eimeria spp., Strongyloides spp. were found in these animals at $3 \times 10^{2}$ egg per gram. These animals were at a body condition of 3 out of 5 with serum biochemical and haematological values showing no evidence of parasitic infection (Jones et al., 2019a) The results of this experiment are in agreement with Jones and Garcia (2017, 2018b) which demonstrated that anthelmintic use did not improve the animal's performance; all animals had a body condition of 4 out of 5 .

The ability of the non-treated group to perform as well as the treated group proposes that the agouti may have an inherent ability in handling endoparasites of 
the gastrointestinal tract. These results showed that anthelmintics were not required in the intensive production of the agouti as has been seen in domesticated livestock reared in the neo-tropics.

\section{Conclusion}

Deworming weaned agoutis that were intensively reared had no significant effect on the growth, dressing percentage (hot and cold), weight of the carcass, kidneys, head, feet, heart, GIT and skin. However, deworming had a significant effect on the weight of the liver and ultimately the weight of the pluck. The agouti had dressing percentage of $55 \%$ to $57 \%$ which to the authors knowledge was the first time this information was recorded in the literature. The dressing percentage recorded for the agouti was in similar range to the capybara and the collared peccary.

\section{Recommendations}

Work can be done to document the effect of anthelmintic drugs on the reproductive efficiency of the agouti and other Neo-tropical animals. Parameters that should be measured should include birth weights, litter weights, litter sizes and sex ratios.

\section{Acknowledgements}

This research was funded by Campus Research and Publication Fund (CRP. 5. OCT.18.92 (1)) of the University of the West Indies, St. Augustine Campus

\section{References}

ALBUQUERQUE, N.I., GUIMARAES, D.A., DIAS, H.L.T., LE PENDU, Y., KAHWAGE, P.R. and GARCIA, A.R., 2010. Intensive production systems of collared peccare (Pecari tajacu) in Brazilian Amazon. Advances in Animal Biosciences, vol. 1, no. 2, pp. 580-581.

ALBUQUERQUE, N.I., GUIMARAES, D.A., DIAS, H.L.T., TEIXEIRA, P.C. and MOREIRA, J.A., 2012. Use of palm kernel cakes (Elaeis guineensis and Orbignya phalerata), co-products of the biofuel industry, in collared peccary (Pecari tajacu) feeds. In: H.P.S. MAKKAR. Biofuel Co-Products as Livestock Feed: Opportunities and challenges. Rome: FAO, pp. 263-273.

BAAS, E.J., POTKAY, S. and BACHER, J.D., 1976. The agouti (Dasyprocta spp.) in biomedical research in captivity. Laboratory Animal Science, vol. 26, no. 5, pp. 788-800. PMid:185455.

BROWN-UDDENBERG, R., GARCIA, G.W., BAPTISTE, Q.S., COUNAND, T., ADOGWA, A.O. and SAMPSON, T., 2004. The Agouti (Dasyprocta leporina, D. agouti) Booklet and Production Manual. St. Augustine, Trinidad: GWG Publications.

CAMERON, T.W.M. and REESAL, M.R., 1951. Studies on the endoparasitic fauna of Trinidad mammals. Canadian Journal of Zoology, vol. 29, no. 4, pp. 276-289. http://dx.doi.org/10.1139/ z51-025.

CASSONE, J. and DURETTE-DESSET, M.C., 1991. Five species (three new) of trichostrongylid nematodes coparasites of Dasyprocta azarae, from Paraguay. Revue Suisse de Zoologie, vol. 98, no. 1, pp. 229-242. http://dx.doi.org/10.5962/bhl.part.79786.
DA SILVA, M.K., DA SILVA, A.S., OLIVIERIA, C.M. and MONTIERO, S.G., 2008. Gastrointestinal parasites of the agouti (Dasyprocta leporina). Ciência Animal Brasileira, vol. 9, no. 1, pp. 128-131.

DOOKIE, B., JONES, K.R., MOHAMMED, R. and GARCIA, G.W., 2018. Garcia. Feed particle size preference and feed wastage in Agouti (Dasyprocta leporina) reared intensively in the Republic of Trinidad and Tobago. Livestock Research for Rural Development, vol. 30, pp. 1-6.

DUBOST, G. and HENRY, O., 2006. Comparison of Diets of the Acouchy, Agouti and Paca, the Three Largest Terrestrial Rodents of French Guianan Forests. Journal of Tropical Ecology, vol. 22, no. 6, pp. 641-651. http://dx.doi.org/10.1017/S0266467406003440.

EISENBERG, J. and REDFORD, K., 1999. Mammals of the Neotropics. Chicago and London: The University of Chicago Press, vol. 3, pp. 436-466.

EMMONS, L. and FEER, F., 1997. Neo-tropical Rainforest Mammals: A field guide. Chicago. London University of Chicago Press.

FIGUEIRA, L., ZUCARATTO, R., PIRES, A.S., CID, B. and FERNANDEZ, F.A.S., 2014. Carrion Consumption by Dasyprocta leporina (Rodentia: Dasyproctidae) and a review of meat use by Agoutis. Brazilian Journal of Biology = Revista Brasileira de Biologia, vol. 74, no. 3, pp. 585-587. http://dx.doi.org/10.1590/bjb.2014.0087. PMid:25296206.

GARCIA, G.W., BAPTISTE, Q.S., ADOGWA, A.O., KAKUNI, M., ARISHIMA, K. and MAKITA, T., 2000. The digestive system of the Agouti (Dasyprocta leporina)-Gross Anatomy and Histology. Japanese Journal of Zoo and Wildlife Medicine, vol. 5, no. 1, pp. 55-66. http://dx.doi.org/10.5686/jjzwm.5.55.

GONCALVES, A.Q., PINTO, R.M. and DURETTE-DESSET, M.C., 2007. Parasitism of two zoonotic reservoirs Dasyprocta leporina and Dasyprocta fuliginosa (Rodentia) from the Amazonas with trichostrongylina nematodes (Heligmonellidae): description of a new genus and a new species. Memorias do Instituto Oswaldo Cruz, vol. 102, no. 6, pp. 763-768. http://dx.doi.org/10.1590/ S0074-02762007000600017. PMid:17924008.

GRIFFITHS, H.J., 1940. Studies on Strongyloides agoutii from the agouti (Dasyptocta agouti). Canadian Journal of Research, Section D; Zoological Sciences, vol. 18, no. 5, pp. 173-190. http://dx.doi. org/10.1139/cjr40d-015.

HARDOUIN, J., THYS, E., JOIRIS, V. and FIELDING, D., 2003. Minilivestock breeding with indigenous species in the tropics. Livestock Research for Rural Development, vol. 15, pp. 4.

HENDRIX, C.M. and ROBINSON, E.D., 2016. Diagnostic Parasitology for Veterinary Technicians-E-Book. Amsterdam, NY: Elsevier Health Sciences.

HENRY, O., 1999. Frugivory and the importance of seeds in the diet of the Orange-Rumped Agouti (Dasyprocta leporina) in French Guiana. Journal of Tropical Ecology, vol. 15, no. 3, pp. 291-300. http://dx.doi.org/10.1017/S0266467499000826.

JONES, K.R. and GARCIA, G.W., 2017. A survey of the gastrointestinal parasites present in the Agouti (Dasyprocta leporina) reared intensively in Trinidad. Livestock Research for Rural Development, vol. 29, no. 10 , pp. 1-7.

JONES, K.R. and GARCIA, G.W., 2018a. Gastrointestinal parasites of domesticated animals introduced into the Neo-tropics (New World Tropics). Concepts Dairy Vet. Sci., vol. 1, no. 2, pp. 156-186.

JONES, K.R. and GARCIA, G.W., 2018b. Observations on endoparasitic load in captive reared agoutis (Dasyprocta leporina) without anthelmintic exposure in Trinidad, Republic of Trinidad and Tobago. Livestock Research for Rural Development, vol. 30, no. 10, pp. 1-7. 
JONES, K.R., and GARCIA, G.W., 2019. Endoparasites of domesticated animals that originated in the neo-tropics (new world tropics). Veterinary Sciences, vol. 6, no. 1, p. 24.

JONES, K.R., LALL, K.R. and GARCIA, G.W., 2019a. Haematological and Serum biochemical values of the agouti (Dasyprocta leporina) reared intensively in Trinidad, Republic of Trinidad and Tobago. Livestock Research for Rural Development, vol. 31, no. 1, pp. 1-8.

JONES, K.R., LALL, K.R. and GARCIA, G.W., 2019b. Omnivorous behaviour of the Agouti (Dasyprocta leporina): A Neo-tropical rodent with the potential for domestication. Scientifica, vol. 2019, pp. 1-5. https://doi.org/10.1155/2019/3759783.

JONES, K.R., LALL, K.R. and GARCIA, G.W., 2019c. Endoparasites of non-domesticated mammals from the Neo-tropics (New World Tropics). Veterinary Sciences, vol. 6, no. 4, pp. 87. http://dx.doi. org/10.3390/vetsci6040087. PMid:31671585.

LAINSON, R., CARNEIRO, L. and SILVEIRA, F.T., 2007. Observations on the Eimeria species of the Dasyprocta leporina (Linnaeus, 1758) (Rodentia: Dasyproctidae) for the state of Para, North Brazil. Memorias do Instituto Oswaldo Cruz, vol. 102, no. 2, pp. 183-189. http://dx.doi.org/10.1590/S0074-02762007005000008. PMid:17426883.

LALL, K.R., JONES, K.R. and GARCIA, G.W., 2018a. Nutrition of six selected neo-tropical Mammals in Trinidad and Tobago with the Potential for Domestication. Veterinary Sciences, vol. 5, no. 2, pp. 52. http://dx.doi.org/10.3390/vetsci5020052. PMid:29757965.

LALL, K.R., JONES, K.R. and GARCIA, G.W., 2018b. Infectious diseases of six non-domesticated neo-tropical animals in Trinidad and Tobago. International Journal of Tropical Veterinary and Biomedical Research, vol. 3, no. 2, pp. 1-31. http://dx.doi.org/10.21157/ ijtvbr.v3i2.12332.

MCWILLIAMS, D.A., 2009. Determinants of capture reared diets for the agouti (Dasyprocta spp.). The Veterinary Clinics of North America. Exotic Animal Practice, vol. 12, pp. 279-286. http:// dx.doi.org/10.1016/j.cvex.2009.01.001. PMid:19341954.

NATIONAL RESEARCH COUNCIL - NRC, 1991. Microlivestock: littleknown small animals with a promising economic future. National Academic Press.

NUNES, A.V., GUARIENTO, R.G., SANTOS, B.A. and FISHER, E., 2019. Wild meat sharing among indigenous people in the southwestern Amazon. Behavioral Ecology and Sociobiology, vol. 73, no. 2, pp. 26. http://dx.doi.org/10.1007/s00265-018-2628-x.

PINHEIRO, M.S. and MOREIRA, J.R., 2012. Products and uses of Capybara. In: J.R. MOREIRA, K.M. FERRAZ, E.A. HERRERA, D.W. MACDONALD, eds. Capybara: Biology, use and conservation of an exceptional neotropical species. New York, NY: Springer, pp. 221-237.
RAMDIAL, B.S. and RAMDIAL, B.P., 1974. The Natural History and Ecology of the Agouti (Dasyprocta agouti): A literature review (Trinidad and Tobago); Mapping and control section, lands and surveys division. Port of Spain, Trinidad and Tobago: Government of Trinidad and Tobago.

RAMOS, D.G.S., SANTOS, A.R.G.L.O., FREITAS, L.C., CORREA, S.H.R., KEMPE, G.V., MORGADO, T.O., AGUIAR, D.M., WOLF, R.W., ROSSI, R.V., SINKOC, A.L. and PACHECO, R.C., 2016. Endoparasites of wild animals form three biomes in the State of Mato Grosso, Brazil. Arquivo Brasileiro de Medicina Veterinária e Zootecnia, vol. 68, no. 3, pp. 571-578. http://dx.doi.org/10.1590/1678-4162-8157.

SAADOUN, A. and CABRERA, M.C., 2008. A review of the nutritional content and technological parameters of indigenous sources of meat in South America. Meat Science, vol. 80, no. 3, pp. 570-581. http://dx.doi.org/10.1016/j.meatsci.2008.03.027. PMid:22063568.

SILVIUS, K.M. and FRAGOSO, J.M.V., 2003. Red-Rumped Agouti (Dasyprocta leporina) home range use in an Amazonian Forest: Implications for the Aggregated Distribution of Forest Trees. Biotropica, vol. 35, no. 1, pp. 74-83. http://dx.doi. org/10.1111/j.1744-7429.2003.tb00264.x.

SMITH, R.L. and SMITH, P., 2019. Wild observations of infanticide and cannibalism be Azara's Agouti (Dasyprocta azarae) (Mammalia: Dasyproctidae) in Paraguay. Ethology, vol. 00, pp. 1-5. http:// dx.doi.org/10.1111/eth.12937.

SOULSBY, E.J., 1968. Helminths, Arthropods and Protozoa of Domesticated Animals. Philadelphia, PA: Lea \& Febiger.

SUEPAUL, R., CHARLES, R. and DZIVA, F., 2016. Aerobic microflora and endoparasites of freshly shot wild Agouti (Dasyprocta leporina) in Trindad, West Indies. Journal of Zoo and Wildife Medicine, vol. 47, no. 4, pp. 1044-1048. http://dx.doi.org/10.1638/20150055.1. PMid:28080916.

THOMAS, S.M. and MORGAN, E.R., 2013. Effect on performance of weanling alpacas following treatments against gastro-intestinal parasites. Veterinary Parasitology, vol. 198, no. 1-2, pp. 244-249. http://dx.doi.org/10.1016/j.vetpar.2013.08.010. PMid:24021542.

ULLMAN-CULLERE, M. and FOLTZ, C., 1999. Body Condition Scoring: A rapid and accurate method for assessing health status in mice. Laboratory Animal Science, vol. 49, no. 3, pp. 313-323. PMid:10403450.

ZIMMERMAN, D.M., DOUGLASS, M., REAVILL, D.R. and GREINER, E.C., 2009. Echinococcus oligarthrus cystic hydatidosis in Brazillian agouti (Dasyprocta leporina). Journal of Zoo and Wildlife Medicine, vol. 40, no. 3, pp. 551-558. http://dx.doi.org/10.1638/20090004.1. PMid:19746872. 